\title{
Primary Ewing Sarcoma of the Thyroid-Eight Cases in a Decade: A Case Report and Literature Review
}

\author{
Paweł Kabata', Sonia Kaniuka-Jakubowska ${ }^{2 *}$, Wanda Kabata ${ }^{3}$, Joanna Lakomy ${ }^{4}$, \\ Wojciech Biernat ${ }^{4}, K_{\text {rzysztof Sworczak }}^{2}$, Janusz Jaśkiewicz ${ }^{1}$ and Maciej Świerblewski ${ }^{1}$ \\ ${ }^{1}$ Department of Surgical Oncology, Medical University of Gdańsk, Gdańsk, Poland, ${ }^{2}$ Department of Endocrinology and \\ Internal Medicine, Medical University of Gdańsk, Gdańsk, Poland, ${ }^{3}$ Wanda Kabata General Practice, WJS Ltd., Gdańsk, \\ Poland, ${ }^{4}$ Department of Pathomorphology, Medical University of Gdańsk, Gdańsk, Poland
}

Sarcomas represent less than $1 \%$ of all malignant tumors found in the thyroid. Of these, primary extraosseoussarcoma has been reported only a few times in the past decade. We present the case of a 34-year-old male who had a fast-growing hard mass in the lower left neck. FNA was inconclusive. Core needle biopsy revealed the diagnosis of an Ewing sarcoma/primitive neuroectodermal tumor. Mutation of EWSR1 was confirmed using the FISH method. Following treatment by neoadjuvant chemotherapy, we observed clinical, radiological, and finally histopathological remission. This was followed by a left-sided isthmolobectomy with unilateral cervical lymph node dissection by lateral lymphadenectomy, which revealed no residual disease. Posttreatment radiotherapy was administered but discontinued upon the patient's request. After 18 months of observation, the patient had no recurrence or metastasis and required L-thyroxine supplementation. We discuss our case using a comparative literature review to the few other known case reports.

Keywords: thyroid sarcoma, Ewing sarcoma, extraosseus ewing sarcoma, ewing's sarcoma of the thyroid, thyroid ewing sarcoma

\section{INTRODUCTION}

Sarcomas represent only a few percent of all neoplasms found in the thyroid, appearing in less than $1 \%$ of all patients treated for malignant thyroid tumors (1). The most commonly found histological types are angiosarcoma, malignant hemangioendothelioma, malignant fibrous histiocytoma, leiomyosarcoma, and fibrosarcoma (2).

Ewing sarcoma is most often found in children, being the second most common malignant bone tumor in this age group. However, its extraskeletal localization is found in approximately $20 \%$ of patients, most often in the thorax and abdomen (43\%), with only $8 \%$ of these tumors being located in the head and neck region (3).

We present the case of a patient who underwent successful multimodal treatment for extraosseous Ewing sarcoma located in the thyroid. Additionally, a comparative literature review of other reported cases was performed and is discussed.

\section{MATERIALS AND METHODS}

For the literature review, PubMed, Google Scholar, and Medline databases were searched using the terms: thyroid sarcoma, Ewing sarcoma, extraosseous Ewing sarcoma. The search covered publications from 2007. Only papers describing primary tumors were considered and four fulltext articles were identified. Two other cases were extracted from a case series describing Ewing 
TABLE 1 | Clinicopathological features of reviewed cases.

\begin{tabular}{|c|c|c|c|c|c|c|c|c|}
\hline Reference & Adapa et al. (5) & Chan et al. (6) & Chan et al. (6) & Maldi et al. (7) & Chirila et al. (8) & Bishop et al. (4) & Bishop et al. (4) & Present case \\
\hline Age & 9 & 23 & 67 & 66 & 48 & 19 & 36 & 34 \\
\hline Sex & $\mathrm{F}$ & M & $\mathrm{F}$ & M & M & M & $\mathrm{F}$ & M \\
\hline $\begin{array}{l}\text { Tumor } \\
\text { presentation }\end{array}$ & $\begin{array}{l}\text { Smooth, non-tender, } \\
\text { rubbery mass }\end{array}$ & $\begin{array}{l}\text { Asymptomatic right neck } \\
\text { mass }\end{array}$ & $\begin{array}{l}\text { Increase of a } \\
\text { previously observed } \\
\text { nodule }\end{array}$ & $\begin{array}{l}\text { Single nodule } \\
\text { discovered in a } \\
\text { follow-up PET scan } \\
\text { after treatment of } \\
\text { B-cell lymphoma }\end{array}$ & $\begin{array}{l}\text { Acute obstructive } \\
\text { respiratory failure } \\
\text { secondary to thyroid } \\
\text { swelling }\end{array}$ & Growing neck mass & Goiter & Fast-growing hard mass \\
\hline Lymph nodes & $(-)$ & $(-)$ & $(-)$ & $(-)$ & N/A & $\mathrm{N} / \mathrm{A}$ & $\mathrm{N} / \mathrm{A}$ & $(-)$ \\
\hline Ultrasound & $\begin{array}{l}\text { Solid, heterogenous, } \\
\text { hypervascular mass. } \\
\text { Left lobe and isthmus } \\
\text { normal }\end{array}$ & $47 \mathrm{~mm}$ right thyroid mass & $\begin{array}{l}\text { Increase from } 4 \text { to } \\
40 \mathrm{~mm}\end{array}$ & $\begin{array}{l}\text { Solid } 45 \mathrm{~mm} \\
\text { heterogenous, } \\
\text { hypervascular }\end{array}$ & N/A & $\mathrm{N} / \mathrm{A}$ & $\mathrm{N} / \mathrm{A}$ & $\begin{array}{l}\text { Pathological mass } \\
\text { filling the whole left lobe } \\
79 \mathrm{~mm} \times 44 \mathrm{~mm} \times 84 \mathrm{~mm}\end{array}$ \\
\hline $\begin{array}{l}\text { Computed- } \\
\text { tomography/ } \\
\text { MRI }\end{array}$ & $\begin{array}{l}\text { Heterogenous mass } \\
\text { with peripheral } \\
\text { enhancement. } \\
\text { Displacement of } \\
\text { trachea, compression } \\
\text { of IJV }\end{array}$ & $\mathrm{N} / \mathrm{A}$ & N/A & N/A & N/A & N/A & $\mathrm{N} / \mathrm{A}$ & $\begin{array}{l}\text { Pathological mass } \\
58 \mathrm{~mm} \times 60 \mathrm{~mm} \text {. Deviation of } \\
\text { trachea. Non-specific lymph } \\
\text { nodes in neck and upper } \\
\text { mediastinum }\end{array}$ \\
\hline Dissemination & $(-)$ & $(-)$ & $(-)$ & N/A & $\begin{array}{l}\text { Metastases to brain } \\
\text { after } 1 \text { month }\end{array}$ & $(-)$ & $(-)$ & $(-)$ \\
\hline $\begin{array}{l}\text { Thyroid function } \\
\text { tests }\end{array}$ & Normal & Normal & N/A & Normal & N/A & $\mathrm{N} / \mathrm{A}$ & $\mathrm{N} / \mathrm{A}$ & Normal \\
\hline $\begin{array}{l}\text { Fine needle } \\
\text { biopsy }\end{array}$ & $\begin{array}{l}\text { Suggestion of } \\
\text { hematologic } \\
\text { malignancy with nodal } \\
\text { involvement }\end{array}$ & Not performed & $\begin{array}{l}\text { Follicular neoplasm or } \\
\text { lesion suspicious for } \\
\text { follicular neoplasm }\end{array}$ & $\begin{array}{l}\text { Thyroid localization } \\
\text { of lymphoma }\end{array}$ & $\begin{array}{l}\text { Giant B-cell non- } \\
\text { Hodgkin lymphoma }\end{array}$ & $\mathrm{N} / \mathrm{A}$ & $\mathrm{N} / \mathrm{A}$ & $\begin{array}{l}\text { Small-cell malignant neoplasm, } \\
\text { most likely of hematologic origin }\end{array}$ \\
\hline $\begin{array}{l}\text { Core needle } \\
\text { biopsy/ } \\
\text { postoperative } \\
\text { pathology }\end{array}$ & $\mathrm{N} / \mathrm{A}$ & $\begin{array}{l}\text { Round epithelioid cells } \\
\text { arranged in nests; tumor } \\
\text { cells mixed with normal } \\
\text { parenchyma or forming } \\
\text { nests with no thyroid } \\
\text { parenchyma; round to } \\
\text { elongated nuclei with } \\
\text { stippled chromatin; } \\
\text { extensive angiolymphatic } \\
\text { invasion }\end{array}$ & N/A & $\begin{array}{l}\text { Malignant tumor } \\
\text { of possible } \\
\text { neuroectodermal } \\
\text { origin }\end{array}$ & $\begin{array}{l}\text { Extraosseous Ewing } \\
\text { sarcoma/primitive } \\
\text { neuroectodermal } \\
\text { tumor }\end{array}$ & $\begin{array}{l}\text { Uniform small } \\
\text { cells; areas of } \\
\text { nested growth with } \\
\text { prominent fibrosis } \\
\text { separating tumor } \\
\text { lobules; colonization } \\
\text { of underlying } \\
\text { follicles; zones of } \\
\text { microcystic growth } \\
\text { set in a prominent } \\
\text { myxoid stroma }\end{array}$ & $\begin{array}{l}\text { Uniform small } \\
\text { cells; areas of } \\
\text { nested growth } \\
\text { with prominent } \\
\text { fibrosis } \\
\text { separating } \\
\text { tumor lobules; } \\
\text { colonization } \\
\text { of underlying } \\
\text { follicles }\end{array}$ & $\begin{array}{l}\text { Small-blue-round-cell tumor } \\
\text { suggesting Ewing sarcoma/ } \\
\text { primitive neuroectodermal tumor }\end{array}$ \\
\hline
\end{tabular}


TABLE 1 | Continued

\begin{tabular}{|c|c|c|c|c|c|c|c|c|}
\hline $\mathrm{IHC}$ & $\begin{array}{l}\text { Vimentin (+) NSE } \\
(+) \text { CD99/O13 (+) } \\
\text { hematopoietic markers } \\
(-)\end{array}$ & $\begin{array}{l}\text { CD99 (+) synaptophysin } \\
(+) \text { chromogranin (+) TTF } \\
\text { (-) PAX8 (-) CK7 (-) CK20 } \\
(-) \text { CK56 (-) CEA (-) } \\
\text { desmin (-) }\end{array}$ & $\begin{array}{l}\text { CD99 (+) vimentin (+) } \\
\text { pankeratin (+) AE1/3 } \\
(+) \text { TTF (-) PAX8 (-) } \\
\text { CEA (-) calcitonin } \\
(-) \text { CD56 (-) CK7 } \\
(-) \text { CK20 (-) CK5/6 } \\
(-) \text { chromogranin (-) } \\
\text { synaptophysin (-) }\end{array}$ & $\begin{array}{l}\text { Vimentin (+) } \\
\text { CD99 (+) NSE (+) } \\
\text { synaptophysin (+) }\end{array}$ & N/A & $\begin{array}{l}\text { CD } 99(+) \text { CK (+) } \\
\text { synaptophysin }(-) \\
\text { chromogranin }(-) \\
\text { S100 (focally+) actin } \\
\text { (focally+) desmin }(-) \\
\text { NUT-1 }(-)\end{array}$ & $\begin{array}{l}\text { CD } 99(+) \\
\text { CK (+) } \\
\text { synaptophysin } \\
(+) \\
\text { chromogranin } \\
\text { (focally+) S100 } \\
(-) \text { actin }(-) \\
\text { desmin (-) }\end{array}$ & $\begin{array}{l}\text { Synaptophysin (+) CD99 (+) PAS } \\
(+) \text { CKAE1/AE3 (+) Cam } 5.2(+) \\
\text { TTF1 (-) calcitonin (-) Bcl2 (-) } \\
\text { LCA (-) }\end{array}$ \\
\hline $\begin{array}{l}\text { ESWR1 } \\
\text { translocation }\end{array}$ & $(+)$ & $(+)$ & $(+)$ & $(+)$ & N/A & $(+)$ & $(+)$ & $(+)$ \\
\hline Surgery & $\begin{array}{l}\text { Right isthmolobectomy } \\
\text { with resection of strap } \\
\text { muscles }\end{array}$ & $\begin{array}{l}\text { Thyroidectomy followed } \\
\text { by lateral and central neck } \\
\text { dissection }\end{array}$ & $\begin{array}{l}\text { Right lobectomy } \\
\text { followed by complete } \\
\text { left thyroidectomy }\end{array}$ & Total thyroidectomy & $\begin{array}{l}\text { Nearly complete } \\
\text { resection of } \\
\text { the tumor with } \\
\text { laryngectomy and } \\
\text { resection of five } \\
\text { tracheal rings }\end{array}$ & $\begin{array}{l}\text { Performed, not } \\
\text { otherwise specified }\end{array}$ & $\begin{array}{l}\text { Performed, } \\
\text { not otherwise } \\
\text { specified }\end{array}$ & $\begin{array}{l}\text { Left isthmolobectomy with } \\
\text { cervical lymphadenectomy }\end{array}$ \\
\hline Chemotherapy & $\begin{array}{l}\text { Vincristine, } \\
\text { doxorubicin, } \\
\text { cyclophosphamide, } \\
\text { iphosphamide, } \\
\text { etoposide, and mesna }\end{array}$ & $\begin{array}{l}\text { Vincristine, actinomycin } \\
\text { D, cyclophosphamide, } \\
\text { doxorubicin, ifosfamide, } \\
\text { etoposide }\end{array}$ & $\begin{array}{l}\text { Cyclophosphamide, } \\
\text { doxorubicin, } \\
\text { vincristine, ifosfamide, } \\
\text { mesna, etoposide }\end{array}$ & None & $\begin{array}{l}\text { CHOP primary } \\
\text { lymphoma } \\
\text { diagnosis, } \\
\text { etoposide, and } \\
\text { carboplatin }\end{array}$ & N/A & N/A & $\begin{array}{l}\text { Doxorubicin, cyclophosphamide, } \\
\text { vincristine, iphosphamide, } \\
\text { etoposide, and mesna }\end{array}$ \\
\hline Pre/postsurgery & Presurgery & Postsurgery & Postsurgery & $\begin{array}{l}\text { Disqualified } \\
\text { because of } \\
\text { significant } \\
\text { comorbidities }\end{array}$ & Postsurgery & Postsurgery & Postsurgery & Presurgery \\
\hline $\begin{array}{l}\text { Response to } \\
\text { treatment }\end{array}$ & Good & $\mathrm{N} / \mathrm{A}$ & Good & $\begin{array}{l}\text { Metastases in } \\
\text { follow-up }\end{array}$ & $\begin{array}{l}\text { Died from brain } \\
\text { metastases after one } \\
\text { cycle }\end{array}$ & $\begin{array}{l}\text { Awaiting } \\
\text { chemotherapy }\end{array}$ & $\begin{array}{l}\text { Awaiting } \\
\text { chemotherapy }\end{array}$ & Complete clinical response \\
\hline Follow up & 6 years & $\mathrm{N} / \mathrm{A}$ & 22 months & 8 months & 1 month & 0 month & 0 month & 18 months \\
\hline Radiotherapy & Yes & Yes & No & No & No & $\mathrm{N} / \mathrm{A}$ & $\mathrm{N} / \mathrm{A}$ & Not completed \\
\hline
\end{tabular}

(+), positive result.

$(-)$, negative result.

N/A, information not available. 


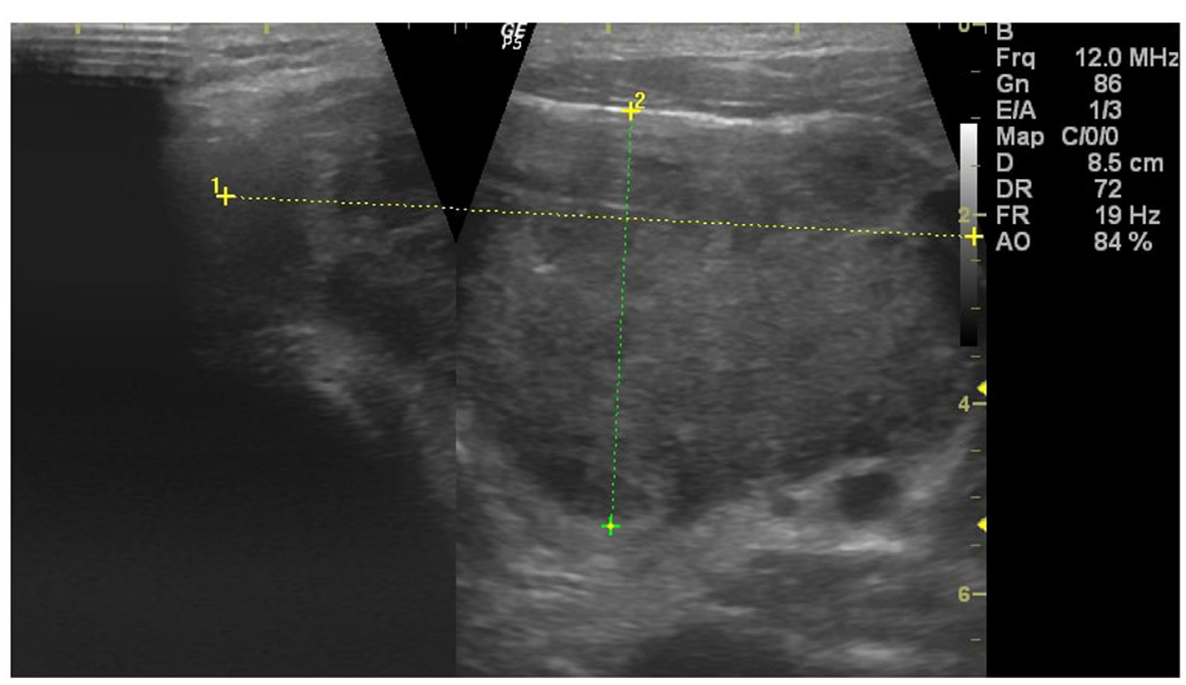

FIGURE 1 | Ultrasound appearance of the tumor.

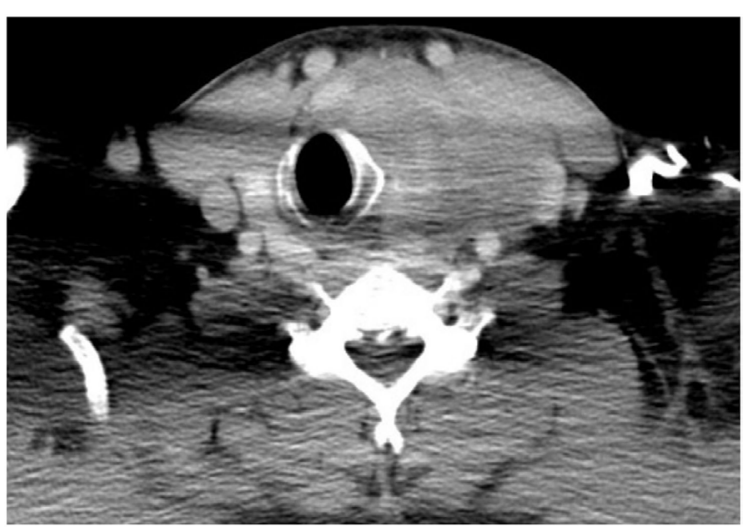

FIGURE 2 | Computed-tomography appearance of the tumor.

family tumors of the head and neck region although, thorough information regarding these cases is limited (4). Detailed available information regarding the reviewed cases is presented in Table 1.

Of the reviewed cases $(N=7)$, most were adult males $(5 / 7$; 57.1\%), 9-67 years, and all displayed growing neck masses without coexisting lymphadenopathy. All patients underwent surgical treatment. Standard chemotherapy regimen for Ewing sarcoma was administered to three of the seven patients, both pre- and postoperatively. One patient did not receive systematic treatment because of significant comorbidities. Information regarding chemotherapy for two of the patients was not available.

Diagnosis of Ewing sarcoma/primitive neuroectodermal tumor was made based on either a core needle biopsy or surgical specimen, and the reports confirmed that six out of seven patients displayed EWSR1 mutation on fluorescence in situ hybridization. One case lacked information on its EWSR1 mutation status. The initial cytological reports uncovered suspected hematologic malignancy in four of the five patients who had fine needle biopsy performed.

Our patient signed an informed consent and granted permission for use of his medical history in this publication.

\section{CASE PRESENTATION}

Our patient, a 34-year-old male, working as a chef, visited a general practitioner with signs of upper respiratory tract infection, sore throat, and difficulties in swallowing. After undergoing a typical prescribed treatment for a cold, the patient's symptoms reportedly resolved. After 3 weeks and no signs of the disease, the symptoms recurred, however, this time, a palpable, fast-growing hard mass in the lower left neck was observed. An ultrasound of the neck revealed a large, solid, hypoechogenic, hypervascular mass with a heterogenous echostructure, and irregular margins in the left lobe of the thyroid. The tumor measured $79 \mathrm{~mm} \times 44 \mathrm{~mm} \times 84 \mathrm{~mm}$ and filled the entire left lobe, but was limited to the thyroid without signs of infiltration of the capsule or surrounding tissues (Figure 1). No pathological lymph nodes were found, except for a few slightly enlarged oval-shaped ones lacking in pathological blood supply. Static elastography assessment showed normal stiffness of the tissue.

The patient was referred to the Department of Surgical Oncology, Medical University of Gdansk for further evaluation. A contrast-enhanced computed-tomography (CT) of the neck, thorax, and abdomen revealed a mass in the left lobe of the thyroid $58 \mathrm{~mm} \times 58 \mathrm{~mm} \times 60 \mathrm{~mm}$, causing tracheal deviation (Figure 2). A number of non-specific, oval-shaped lymph nodes up to $14 \mathrm{~mm}$ were found in the neck and upper mediastinum, with no other pathological lesions being found. A fine needle biopsy was then performed, which revealed a small-celled malignant neoplasm, most likely of hematological origin. Laboratory markers-TSH, T3, T4, LDH were in reference range, respectively: TSH $0.64 \mu \mathrm{U} / \mathrm{ml}$ (0.34-0.94), fT3 $4.9 \mathrm{pmol} / \mathrm{l}(2.63-5.7), \quad$ fT4 $14.28 \mathrm{pmol} / \mathrm{l}$ 


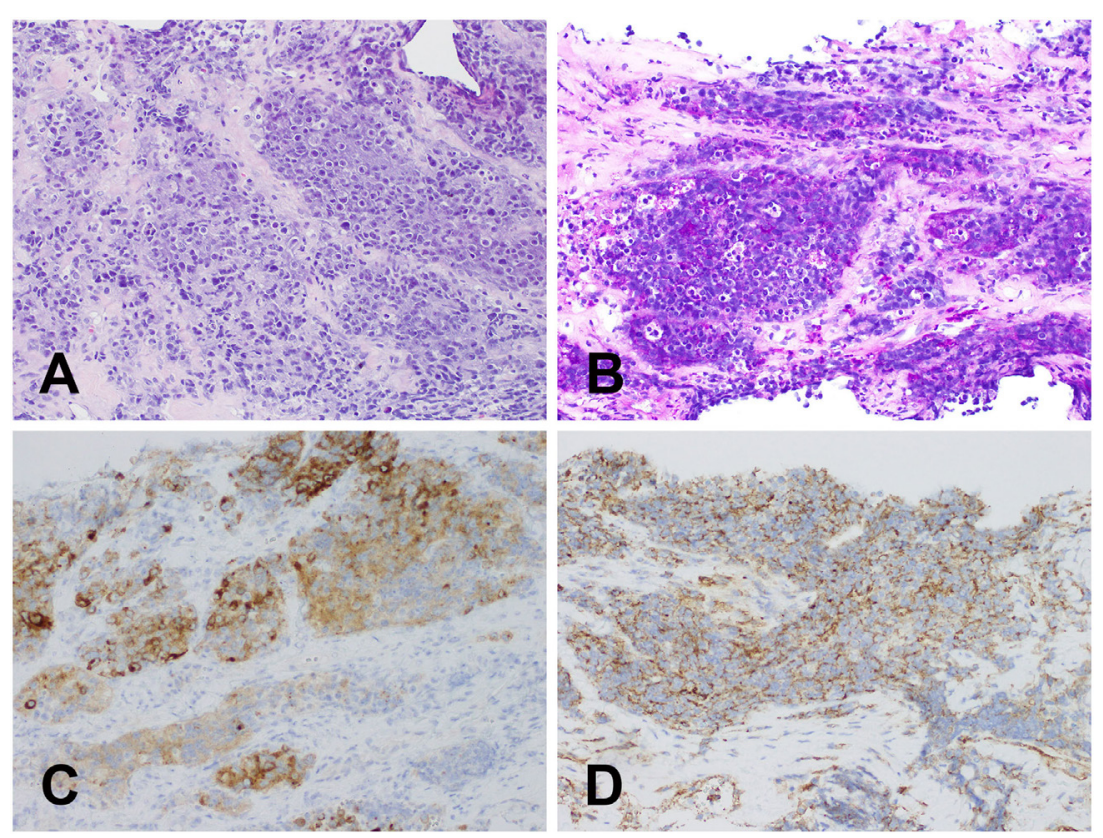

FIGURE 3 | Histologic examination. Core needle biopsy of the tumor: (A) magnification $\times 200$; hematoxylin-eosin staining-small-blue-round-cell tumor; (B) magnification $\times 200$; PAS - positive staining; (C) magnification $\times 200$; S100-positive staining; (D) magnification $\times 200$; CD99-positive staining.

(9.01-19.05), LDH $201 \mathrm{U} / 1$ (125-220) with CEA and calcitonin being negative. As the patient had no previous history of neoplastic disease, core needle biopsy of the tumor was performed. It revealed a small-blue-round-cell tumor with immunophenotype: synaptophysin (+), CD99 (+), PAS (+), CKAE1/AE3 (+), Cam $5.2(+)$, TTF1 (-), calcitonin $(-), \operatorname{Bcl} 2(-)$, and LCA $(-)$, which suggested a Ewing sarcoma/primitive neuroectodermal tumor (Figure 3). Mutation in EWSR1 was confirmed using the FISH (fluorescence in situ hybridization) method.

After a multidisciplinary team consultation, which included surgical, medical, and radiation oncology opinions, the patient qualified for neoadjuvant chemotherapy with doxorubicin $25 \mathrm{mg} / \mathrm{m}^{2}$, cyclophosphamide $1,200 \mathrm{mg} / \mathrm{m}^{2}$, vincristine $2 \mathrm{mg}$, iphosphamide $3.6 \mathrm{~g}$, etoposide $200 \mathrm{mg}$, and mesna. After six cycles of chemotherapy, a complete, clinical response was observed and the patient was referred for surgery. Left-sided isthmolobectomy with unilateral cervical lymph node dissection of groups II, III, IV, and V was performed, confirming clinical response to treatment (Figure 4). Postoperative pathological examination reported complete response to therapy with no pathological lesions found in the thyroid. All 28 lymph nodes removed were free from malignant cells.

During the postoperative period, mild left-sided Horner's syndrome was observed, which resolved spontaneously after 2 weeks. The patient was discharged home on the fifth day following surgery and was then followed up during his visits to the surgical outpatient clinic until wound healing was complete. He then started adjuvant radiotherapy, which was discontinued because of dysphagia. The patient has currently undergone oncological follow-up and observation for 18 months with no signs of recurrence or dissemination of the disease. 16 months

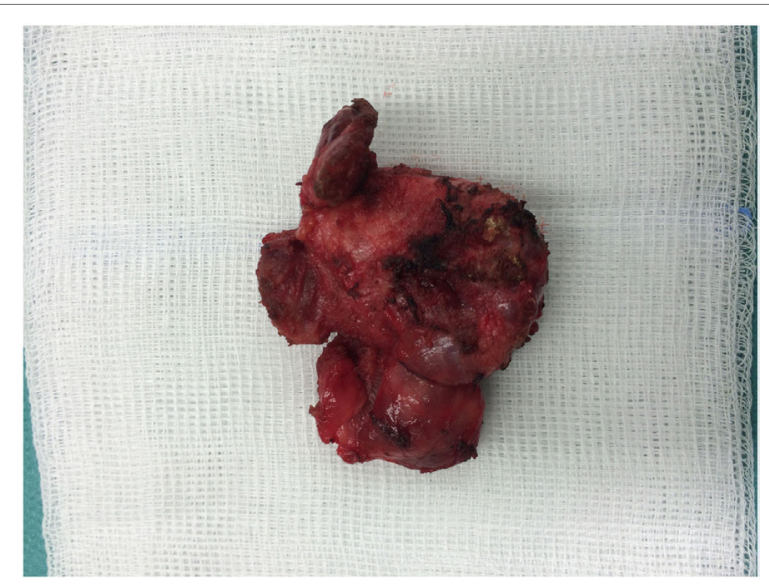

FIGURE 4 | Postoperative specimen-left lobe of the thyroid with the isthmus.

postsurgically, when TSH level was of $6.6 \mu \mathrm{U} / \mathrm{ml}(0.34-4.94)$ we started supplementation of L-thyroxine.

\section{DISCUSSION}

Ewing sarcoma/primitive neuroectodermal tumors are a group of small-, round-celled tumors, with different degrees of neuroectodermal differentiation (7). These neoplasms are most commonly found localized in the skeletal system of pediatric patients. Primary extraosseous Ewing sarcomas of the thyroid are extremely rare and have only been reported a few times in 
the past decade. Other types of sarcoma such as angiosarcoma or malignant hemangioendothelioma are found more frequently, but still play a minor role in thyroid oncology.

Diagnosis of thyroid Ewing sarcoma based on its clinical and radiological features or even fine needle biopsy seems to be challenging. The clinical manifestation of malignancy can be a rapidly growing mass, sometimes described as swelling on the neck $(5,6,9)$. The disease displays no features of thyroid gland dysfunction, therefore, the thyroid hormones are within reference ranges. Using an ultrasound, a solid, heterogeneous, hypervascular soft tissue mass within the thyroid was found, which creates a difficulty of differentiating it from other thyroid malignancies $(5,7,9)$. Performing a fine needle biopsy did not obtain a proper diagnosis in any of the reported cases (Table $\mathbf{1}$ ). As shown in our review, using a cytological assessment, these tumors might mimic hematological malignancies, therefore, a core needle specimen should be taken to obtain a proper diagnosis and start adequate treatment.

Because of the scarcity of such cases, no guidelines regarding optimal treatment options are available. All the reviewed cases where detailed information of treatment was available underwent the typical treatment regimen for Ewing sarcoma; however, the timing of chemotherapy differed. According to NCCN guidelines for treatment of Ewing sarcoma, neoadjuvant multi-agent chemotherapy should be administered prior to local therapy (surgery or radiotherapy) (10). As expected, in the treatment of Ewing sarcoma of other organs, our case confirms the efficacy of neoadjuvant therapy. Despite the initially large tumor mass (CT $58 \mathrm{~mm} \times 58 \mathrm{~mm} \times 60 \mathrm{~mm}$ ), following isthmolobectomy with unilateral cervical lymph node dissection, we did not find any malignant cells in the histopathological thyroid specimens. Previous case reports refer only to postsurgery chemotherapy, with the sole exception of neoadjuvant therapy, but the case lacks a response assessment from before surgery. With such a limited number of cases, it is impossible to assess which approach is better; however, we at least know that both are effective and neoadjuvant therapy can provide total remission.

\section{REFERENCES}

1. Ozaslan E, Berk V, Baldane S, Eker B, Bozkurt O, Senol S, et al. Primary pleomorphic rhabdomyosarcoma of thyroid gland in an adult patient: a case report. Eurasian J Med (2016) 48(1):69-72. doi:10.5152/eurasianjmed.2015.96

2. Surov A, Gottschling S, Wienke A, Meyer HJ, Spielmann RP, Dralle H. Primary thyroid sarcoma: a systematic review. Anticancer Res (2015) 35(10):5185-91.

3. Cash T, McIlvaine E, Krailo MD, Lessnick SL, Lawlor ER, Laack N, et al. Comparison of clinical features and outcomes in patients with extraskeletal versus skeletal localized Ewing sarcoma: a report from the Children's Oncology Group. Pediatr Blood Cancer (2016) 63(10):1771-9. doi:10.1002/ pbc. 26096

4. Bishop JA, Alaggio R, Zhang L, Seethala RR, Antonescu CR. Adamantinomalike Ewing family tumors of the head and neck. Am J Surg Pathol (2015) 39(9):1267-74. doi:10.1097/PAS.0000000000000460

5. Adapa P, Chung T-W, Popek EJ, Hunter JV. Extraosseous Ewing sarcoma of the thyroid gland. Pediatr Radiol (2009) 39(12):1365-8. doi:10.1007/s00247009-1388-1

6. Chan JM, Bilodeau E, Celin S, Nikiforov Y, Johnson JT. Ewing sarcoma of the thyroid: report of 2 cases and review of the literature. Head Neck (2013) 35:E346-50. doi:10.1002/hed.23240

7. Maldi E, Monga G, Rossi D, Tosoni A, Mezzapelle R, Boldorini R. Extraosseous Ewing sarcoma of the thyroid gland mimicking lymphoma
Regardless of the timing, chemotherapy is crucial for treatment of this neoplasm.

Standard surgical treatment of Ewing sarcoma does not cover lymphatic resection (10). From the cases reviewed, cervical lymphadenectomy was performed for only one patient, only because medullary thyroid cancer was initially suspected. Postoperatively, lymph node metastases were found. The diagnosis was then verified as being Ewing sarcoma. A complimentary lymphatic resection was performed, which revealed metastases and the patient was referred for adjuvant chemotherapy. Only in our case was information regarding the lymph node ratio after neoadjuvant treatment available, and it showed no metastases in the cervical lymph nodes. In the other cases, where only wide surgical resection was performed, no nodal recurrences were observed. On the other hand, Chinese surgeons reported nodal recurrence of synovial sarcoma of the thyroid in a patient where neck dissection was omitted (9). Therefore, based on the reviewed material, we cannot tell whether lymphadenectomy could be omitted for treatment of Ewing sarcoma of the thyroid. With limited data, coming mostly from case reports and case series, it is impossible to state clear recommendations.

\section{CONCLUSION}

Extraosseous Ewing sarcoma of the thyroid is an extremely rare tumor. Neoadjuvant therapy can provide total histopathological remission before surgery. Because very few literature cases are described, it is difficult to establish a set standard of care. Our case seems to be a confirmation that the standard suggested treatment regimens for Ewing sarcoma can be safely applied for such patients.

\section{AUTHOR CONTRIBUTIONS}

PK, SK-J, MS, and WK managed the case. PK and SK-J drafted the manuscript. PK, SK-J, MS, KS, and JJ reviewed the manuscript. JL and WB prepared histopathological results.

recurrence: a case report. Pathol Res Pract (2012) 208(6):356-9. doi:10.1016/ j.prp.2012.03.005

8. Chirila M, Muresan M, Ciuleanu E, Cosgarea M. Extraosseous Ewing sarcoma and peripheral primitive neuroectodermal tumor of the thyroid gland: case report and review. Ear Nose Throat J (2013) 92(4-5):3-6.

9. Shi R-L, Qu N, Gao L-L, Lu Z-W, Sun G-H, Ji Q-H. Primary synovial sarcoma of the thyroid with locally repeated relapses in short periods: a case report. Biomed Rep (2016) 5(1):79-82. doi:10.3892/br.2016.670

10. National Comprehensive Cancer Network. Bone Cancer (Version 2.2017). (2016). Available from: https://www.nccn.org/professionals/physician_gls/pdf/ bone.pdf

Conflict of Interest Statement: The authors declare that the research was conducted in the absence of any commercial or financial relationships that could be construed as a potential conflict of interest.

Copyright (C) 2017 Kabata, Kaniuka-Jakubowska, Kabata, Lakomy, Biernat, Sworczak, Jaśkiewicz and Swierblewski. This is an open-access article distributed under the terms of the Creative Commons Attribution License (CC BY). The use, distribution or reproduction in other forums is permitted, provided the original author(s) or licensor are credited and that the original publication in this journal is cited, in accordance with accepted academic practice. No use, distribution or reproduction is permitted which does not comply with these terms. 